\title{
MUNHOZ, FELIPE FRANCO. IDENTIDADES. SÃO PAULO: EDITORA NÓS, 2018.
}

\author{
Jorce Vicente Valentim!
}

Caminhar no escuro de sentença para sentença. Mas é isso que me faz seguir em frente.

(Felipe Franco Munhoz. Mentiras, p. 10)

A impressão é de que tudo poderia principiar novamente.

(Felipe Franco Munhoz. Identidades, p. 103)

Um Mefistófeles brasileiro. Esse, talvez, poderia ser o epíteto para se pensar o jovem autor paulistano Felipe Franco Munhoz e seu mais recente romance. Tal como seu primeiro texto, Mentiras, publicado em 2016, este também apresenta um enxugamento na apresentação do título e com uma predileção, nada gratuita, aliás, pelo plural. Identidades (2018) já sugere a pluralidade de situações, tanto as narradas, quanto as estruturais.

Trata-se, no meu entender, de uma verdadeira pérola ficcional no atual cenário da ficção contemporânea de língua portuguesa. A começar pelo tratamento visual da própria materialidade do livro. Rico em imagens de linhas paralelas, numa feliz sugestão de pautas musicais sobrepostas, o romance ainda traz elementos que desestabilizam a tranquilidade, sobretudo daqueles que preferem

1 Professor Adjunto de Literaturas de Língua Portuguesa (Sub-áreas: Literatura Portuguesa e Literaturas Africanas de Língua Portuguesa), do Departamento de Letras da UFSCar e colaborador no Programa de Pós-Graduação em Estudos Literários da UNESP/Araraquara. 
uma leitura rasa e rarefeita do texto literário. Aqui, Felipe Castro Munhoz elabora, lapida, pole e esquadrinha a sua trama com partituras, pautas, fotografias, imagens gráficas, além de enriquecer a formatação visual da narrativa com categorias genológicas que ultrapassam as do romance convencional.

Assim, não será estranho o leitor se deparar com trechos que concretizam uma estruturação poética, além, é claro, da apresentação das personagens em modo de introdução de um texto dramático. Ficção, drama, poesia, música e fotografia são articuladas de forma simbiótica, corroendo os lugares-comuns esperados, num exercício absolutamente heterodoxo em relação à disposição das categorias narrativas. Aliás, como faz em Mentiras, Felipe Franco Munhoz investe de forma madura numa maneira outra de construir o foco narrativo, posto que, em Identidades, uma pergunta fica no ar: afinal, quem é o narrador? Quem é o responsável por juntar e expor toda a efabulação? Fausto? Suposto Mefistófeles? Mefistófeles? Camila? Todos eles ou nenhum deles?

Na verdade, o próprio romance dá pistas deste projeto de narrar muito peculiar: "Durante a frase derradeira, o palco vai desaparecendo na escuridão" (MU$\mathrm{NHOZ}, 2018$, p. 28). Se os recursos dramáticos percorrem toda a trama (que existe, por sinal, apesar da sensação de embaralhamento causada pela sua estrutura fragmentária), depois de cada apagar das luzes (ou os "blecautes", sempre seguidos de uma peça musical, instrumental ou vocal), novos cenários e novas situações vão se interpondo, numa sucessão muito bem pensada, onde Fausto "(que é uma mulher, mas em trajes - e corte de cabelo - semimasculinos)" (MUNHOZ, 2018, p. 29), como bem nos lembra a voz narrativa entre parênteses, em forma mesmo de rubrica teatral, depara-se com o "Suposto Mefistófeles" (MUNHOZ, 2018, p. 33).

$E$, aqui, vou na contramão do que alguns críticos vêm apontando sobre o romance de Felipe Franco Munhoz, posto que acredito que não é exatamente na figura faustiana que reside o verdadeiro trunfo de Identidades. Claro que a leitura da famosa personagem de Goethe, consagrada, posteriormente, nas pautas operísticas de Gounod e Boito, constitui um diálogo intertextual flagrante. Mas, não só. Principalmente, porque não se pode pensar Fausto sem aquele que o colocaria numa tensão geracional, espacial e temporal: Mefistófeles. Não à toa, em Identidades, também este aparece e, agora, sob o signo da pluralidade, já que são três máscaras articuladas dentro da trama: o "Suposto Mefistófeles", o "Suposto Mefistófeles jovem" e o "Mefistófeles". Espécie, talvez, de estilhaça- 
mento da própria categoria de personagem dentro da espessura do romance? Sim, possivelmente, mas aí, o caminho de leitura traçado exigiria um arcabouço psicológico e psicanalítico, abrindo, assim, um outro horizonte de análise.

A própria disposição de um Fausto vivido por uma mulher travestida também propiciaria uma leitura queerezante do romance, colocando em cheque o monolitismo das performances de gênero. Mesmo que não seja essa a ênfase da obra, ela possibilita tal caminho analítico na medida em que, como bem sugere a metáfora de Jorge Luís Borges (1972), vai desbotando o texto como um jardim com caminhos que se bifurcam.

Imagem, aliás, mais que apropriada para pensar esse romance. Intertextual na sua essência, há uma pluralidade de referências musicais ao longo da trama que vão desde Beethoven a Milton Nascimento, de Bach a Mozart, de Tartini a Adrian Leverkühn, de Gounod a Kris Kristofferson, de Martinu a John Cage, de Leonard Cohen a Bob Dylan, além de todo um elenco seletíssimo de canções populares. Todas elas, articuladas com as angústias e as tensões geradas pelo "Suposto Mefistófeles", vão ganhando significados pertinentes ao desenrolar da efabulação. Não se trata, portanto, de uma mera trilha sonora, ou daquilo que chamamos de música incidental, ou seja, música feita para acompanhar uma obra teatral ou audiovisual já pronta (BRENET, 1976). Ao contrário, no meu entender, todas elas são partes integrantes e, juntamente, com Kafka, Dostoievski, Shakespeare, Eliot, Roth e Auster (esses dois últimos em ecos muitos sutis, relembrando, respectivamente, os alter egos em $A$ marca humana, e a relação do escritor com o seu objeto de trabalho, em $A$ história da minha máquina de escrever), compõem um interessante mapeamento dos encontros e desencontros tecidos entre Fausto, Camila e as máscaras de Mefistófeles.

Não me parece, portanto, uma obra de escritor novato ou inexperiente no metier ficcional. Felipe Franco Munhoz investe num projeto amadurecido e com uma verve de escrita madura. Basta observar, neste sentido, as datas de início e conclusão do texto: de 24/08/2015 a 13/01/2017. Ou seja, foram necessários quase dois anos para burilar e trazer à cena o seu romance Identidades. Por outro lado, também não podemos ser ingênuos e acreditar piamente nas informações veiculadas, posto que elas também podem ser mais uma das muitas e salutares armadilhas criadas pelo autor. No entanto, em virtude do caráter altamente trabalhado, sobretudo nas coerentes ligações de cenas após cada blecau- 
te, tendo a dar crédito à voz autoral e, realmente, pensar que o romance passou por um intenso processo de depuração até o seu produto final.

Ou, como próprio autor irá afirmar sobre Fausto, um dos seus protagonistas: "Feito a chama que nunca se apaga" (MUNHOZ, 2018, p. 173). Comentário, aliás, muito autorreferencial e metatexual, na medida em que autor e obra deixam em evidência um espírito de desassossego e inquietação, tanto no que diz respeito ao acabamento estético de suas personagens, quanto no que concerne aos recursos dispostos na criação romanesca.

Neste sentido, a voz de Natália Borges Polesso, leitora sensível e responsável por uma das orelhas da edição, é paradigmática: não se pode ler Identidades munido de clichês e certezas. É preciso, como bem alerta a escritora gaúcha, "uma generosa dose de incompreensão", na medida em que o romance de Felipe Franco Munhoz destila uma série de desafios a serem identificados também pelo leitor. Seja o estético, na costura e na conjugação bem sucedida de referências culturais, seja o estrutural, na reunião de todo este elenco efabulatório dentro do micro espaço de um closet. Mas, não serão as suas criaturas, exatamente, pequenas peças que se encaixam e se embaralham, numa composição lúdica em forma de cubo mágico?

Ora, não à toa, iniciei esta recensão referindo-me ao seu autor como um Mefistófeles brasileiro. Quero lembrar, aqui, a apropriada leitura de Mário Vieira de Carvalho (1999) sobre a personagem musical de Gounod na ficção de Eça de Queirós. Para o ensaísta português, é exatamente a figura diabólica a responsável pela mais ácida das gargalhadas, porque de longe, espreitando cada passo do casal protagonista, contempla as vicissitudes das personagens. De forma muito lúcida, na concepção de Carvalho (1999), Eça de Queirós aproveita esta articulação da personagem operística para tecer também, ao seu modo, um olhar crítico e corrosivo, adotando uma ótica de espreitamento social.

Ainda que saibamos, pelas mãos de lan Watt, que o Fausto constitui um dos mitos mais representativos do individualismo moderno, na medida em que ele "não foi eleito para o panteão da história pelos seus próprios méritos; primeiro, ele teve de ser reinventado pelos desejos e os medos dos outros" (WATT, 1997, p. 37), não se poderá negar que Mefistófeles também possui um papel relevante nos cenários literário e musical, afinal, é ele o articulador responsável pela manipulação das trajetórias das personagens, além de ser um observador atento, pelos cantos e pelas frestas das paredes, de todos os passos de Fausto e Marga- 
rida, na ópera de Gounod (CARVALHO, 1999). Por isso, a sua gargalhada é ácida e pontual. Ele tudo presencia e a todos maneja a seu bel prazer.

Guardadas as devidas diferenças espaciais e temporais (dos Mefistófeles oitocentistas para as máscaras atuais, em Identidades), gosto de pensar que esta também não deixa de ser a atitude última de Felipe Franco Munhoz. Exímio articulador de referências culturais, manipulador maduro das suas criaturas, a ponto de fraturar uma delas em 3 máscaras, e sensível no acabamento do seu projeto literário, parece ser dele mesmo a intencionalidade dos versos (?) iniciais: "Alcei meus pés à ponta corpo rijo / flutuam sobre as minhas mãos palavras / parece até que oferto Livro Verso" (MUNHOZ, 2018, p. 39). Mas, neste exercício de criação, longe de lançar uma gargalhada de deboche e de crítica ácida, a sua parece incidir sobre os constantes convites deixados, como pequenas pistas ao longo das linhas do seu romance, em que o prazer de cada descoberta sugere o reinício de outro ainda por se revelar. De blecaute a blecaute, de música a outra música, de uma cena para outra, as peças/personagens vão se encaixando e se superpondo, num mosaico ambíguo, fluido e revelador.

Interessante observar que a própria relação de todas personagens, já nas páginas iniciais da obra, sugere uma dramatização dentro da própria encenação do romance, afinal, se a referência à opera fica visível com as presenças de Fausto e das articulações sobre Mefistófeles, não é exatamente sobre o espetáculo que Felipe Franco Munhoz se debruça, mas sobre seu ensaio. E tal possibilidade de leitura dá-se pela introdução intencional da personagem "pianista". Ora, no mundo musical operístico (que o autor bem conhece, diga-se de passagem), o pianista tem a função de correpetidor, ou seja, de executar no teclado diversas e quantas vezes necessárias, os trechos e as árias na preparação e na performance dos cantores que desempenham os seus respectivos papéis na montagem da ópera.

Será esta uma artimanha do autor, como em forma de um prenúncio sutil de que se Identidades configura um ensaio, uma preparação, o espetáculo em si ainda estaria por vir num texto por vir?

No meu entender, essa é a doação maior deste Mefistófeles brasileiro. Com domínio e astúcia, Felipe Franco Munhoz oferece generosamente Identidades ao público leitor, não sem deixar de o incitar sedutoramente: "identifique-se! / : Eu?" (MUNHOZ, 2018, p. 84). Atendendo, portanto, ao convite feito na trama, identifico-me, aqui, acreditando não incorrer em exagero quando afirmo, a 
partir dos aspectos acima apontados, que o seu romance de 2018 constitui um grande texto. Na contramão das crises anunciadas da narrativa, o autor oferece formas outras de contar uma bela história de amor à vida e à arte da escrita.

\section{Referências:}

BORGES, Jorge Luis. Fiç̧ões. Tradução de Carlos Nejar. São Paulo: Abril Cultural, 1972. BRENET, Michel. Diccionario de la música. Traduccion: J. Ricardo Matas, José Barberá Humbert e Aurelio Capmany. 3a. ed. Barcelona: Editorial Iberia, 1976.

CARVALHO, Mario Vieira de. Eça de Queirós e Offenbach. A ácida gargalhada de Mefistófeles. Lisboa: Edições Colibri, 1999.

MUNHOZ, Felipe Franco. Identidades. São Paulo: Editora Nós, 2018.

MUNHOZ, Felipe Franco. Mentiras. São Paulo: Editora Nós, 2016.

WATT, Ian. Mitos do individualismo moderno: Fausto, Dom Quixote, Dom Juan, Robinson Crusoe. Tradução de Mário Pontes. Rio de Janeiro: Jorge Zahar Editor, 1997. 